\title{
Rodzaj gramatyczny rzeczownika jako nośnik informacji pozagramatycznej I. Przegląd literatury dotyczącej rodzaju gramatycznego' ${ }^{1}$
}

\section{Grammatical gender of nouns as a means of conveying extragrammatical information $I$. Review of the research concerning grammatical gender}

\author{
Mirosław Koziarski, Adrian P. Krysiak² \\ INSTYTUT JĘZYKOZNAWSTWA, UNIWERSYTET IM. ADAMA MICKIEWICZA \\ AL. NIEPODLEGŁOŚCI 4, 61-874 POZNAŃ \\ miroslaw.koziarski@gmail.com, adrian_krysiak@wp.pl
}

\begin{abstract}
This article aims at investigating the nature of the gender system in Polish. The paper includes a review of various approaches to the problem, as seen by psycholinguistics, neurolinguistics and feminist linguistics, as well as an attempt at presenting a synchronic view on the gender system. It is also the theoretical introduction to a following empirical article treating of Polish genders.
\end{abstract}

Languages differ essentially in what they must convey and not in what they may convey.

Roman Jakobson 3

\footnotetext{
${ }^{1}$ Autorzy pragną wyrazić wdzięczność prof. Piotrowi Wierzchoniowi i dr. Pawłowi Nowakowskiemu z Instytutu Językoznawstwa Uniwersytetu im. Adama Mickiewicza w Poznaniu za lekturę pierwszej wersji tekstu. Adrian Krysiak dziękuje dodatkowo mgr Joannie Fabiszak z Instytutu Polonistyki i Kulturoznawstwa Uniwersytetu Szczecińskiego za pomoc w rozwiązaniu pewnego problemu technicznego oraz mgr Agnieszce SchönhofWilkans z Instytutu Językoznawstwa UAM za konsultację w kwestii języka suahili. Za wszystkie błędy odpowiadają wyłącznie autorzy.

2 Autorzy w równym stopniu uczestniczyli w powstawaniu pracy.

3 Jakobson, R. 1959. On linguistic aspects of translation. w: R.A. Brower (red.) On translation. Cambridge, MA: Harvard University Press. pp. 232-239. Por. interpretację tezy determinizmu i relatywizmu językowego Sapira-Whorfa, którą można (interpretację) wyrazić w przystępnym dictum: „poszczególne języki gramatykalizują różne informacje” (Pogonowski 2006).
} 
Mirostaw Koziarski, Adrian P. Krysiak: Rodzaj gramatyczny...

Jak z wielości cech wydzielić potrzebne, zatrzymać naptywające skojarzenia uboczne, z tysięcy związków wytonić jeden, tylko ten potrzebny? Aleksander Łuria4

\section{Wprowadzenie}

W „Uniwersalnym słowniku języka polskiego” (USJP - Dubisz 2006) rodzaj gramatyczny zdefiniowany jest jako „kategoria morfologiczna rzeczowników decydująca o ich końcówkach deklinacyjnych, o formach innych części mowy określających dany rzeczownik, wchodzących z nim w związek zgody, decydująca także $o$ formach łączących się $z$ nim czasowników”. Innymi słowy, jest to gramatyczna właściwość rzeczowników, która jest dziedziczona po nich przez przymiotniki (a także przymiotne formy zaimków, liczebników czy imiesłowów), a która determinuje, według jakiego sposobu dane wyrazy będą się odmieniały. Rodzaj gramatyczny (Genus) można potraktować również jako wymiar semiczny, rozumiany jako zbiór wszystkich homogenicznych semów (Bańczerowski et al. 1982: 216).

„Wymiar Rodzaju jest odbiciem, przynajmniej
częściowym, pewnych naturalnych własności
przysługujących określonym klasom obiektów, do których
te wyrazy mogą się odnosić. W niektórych językach, w tym
również w polskim, szczególny związek z tym wymiarem
odgrywa rozróżnienie płci, tzn. rodzaju naturalnego istot
żywych. (...) W przypadku przedmiotów nieożywionych
charakterystyka według rodzaju wydaje się
nieuzasadniona” (Bańczerowski et al. 1982: 217).

Według Lyonsa (1976: 315), mimo iż „uznanie rodzaju za kategorię gramatyczną jest logicznie niezależne od jakiegokolwiek jego związku semantycznego $\mathrm{z}$ fizycznymi czy innymi właściwościami osób albo przedmiotów oznaczanych przez rzeczowniki”, to „nie da się zaprzeczyć, że w większości języków posiadających rodzaj (czyli klasyfikację rzeczowników dla celów odniesienia zaimkowego albo zgody) klasyfikacja ta ma pewne naturalne, semantyczne podstawy”, przy czym „podstawą tą może być dowolny zespół właściwości przedmiotu”, na przykład kształt, konsystencja, jadalność czy kolor. Za przykład posłużyć może, analizowany przez Lyonsa (1976: 316-317), system klasyfikacji rzeczowników w języku suahili.

Do powyższych uwag warto dodać, iż w języku polskim (jak również w suahili) rodzaj gramatyczny stanowi przykład informacji zgramatykalizowanej, czyli (i) jest informacją obligatoryjnie wyrażaną w wypowiedziach (ii) jest informacją wyrażaną w sposób regularny (iii) z reguły nie występuje samodzielnie (Pogonowski 2006: 2). Weźmy zdanie:

4 Łuria, A.R. 1981. Świat utracony i odzyskany. Historia pewnego zranienia. Warszawa: PWN. 
1. Młodzi lingwiści napisali kilka artykułów naukowych.

Na podstawie słów młodzi, lingwiści i napisali można wydedukować, iż chodzi o grupę lingwistów, w których skład wchodzi co najmniej jeden przedstawiciel płci męskiej. Zdanie to można przekształcić, ale tylko i wyłącznie z zachowaniem związku zgody:

2. Młode lingwistki napisały kilka artykułów naukowych.

Zdania (1) i (2) stanowią jedyne dwa możliwe warianty tej wypowiedzi, każde niosące wyraźną informację na temat rodzaju gramatycznego, i nie można stworzyć wariantu „neutralnego” w tej kategorii, co dowodzi spełnienia warunku (i). Co więcej, każda próba przemieszczenia form między tymi zdaniami zakończy się otrzymaniem zdania niepoprawnego, np.

3. *Młodzi lingwistki napisali kilka artykułów naukowych.

4. *Młode lingwiści napisali kilka artykułów naukowych.

Zdania takie są łatwo identyfikowane przez natywnych użytkowników języka polskiego jako niepoprawne, dowodząc poprawności warunku (ii). Ponadto każda próba wyrażenia rodzaju gramatycznego wymaga użycia odpowiedniej końcówki wyrazu-nośnika informacji o rodzaju (rzeczownika) oraz części mowy podlegających związkowi zgody, tak jak przewiduje to warunek (iii)5. Innym zdaniem obrazującym wpływ rodzaju gramatycznego na wypowiedź jest rozpowszechnione i niepoprawne „Umieścić cytat w cudzysłowiu” (M. cudzysłowie, r. nijaki) zamiast poprawnego „Umieścić cytat w cudzysłowie” (M. cudzysłów, r. męski).

Definicji kategorii rodzaju gramatycznego można oczywiście znaleźć zgoła wiele - nietrudno przy tym zauważyć, iż jest to kategoria zakresowo bardzo szeroka oraz wysoce niejednolita, gdyż różne części mowy obejmuje w różny sposób. Można więc wyróżnić części mowy związane z rodzajem gramatycznym pierwotnie $\mathrm{i}$ inherentnie, tj. posiadające rodzaj, czyli rzeczowniki (człowiek, osoba, dziecko), oraz te związane wtórnie, przyjmujące rodzaj poprzez związek zgody, czyli przymiotniki (miły, - $a$, -e), liczebniki (dwóch, dwie, dwoje), imiesłowy przymiotne (idacy, -a, -e), zaimki (on, ona, ono; który, $-a,-e$ ), czasowniki w czasie przeszłym (poszedt, poszta, poszto).

Ze względu na wspomnianą niejednolitość inkryminowanej kategorii gramatycznej, badania empiryczne nad rodzajem gramatycznym prowadzone są przez językoznawców różnej orientacji metodologicznej, w

5 Należy tutaj jednak wspomnieć, iż występują pewne wyjątki od tej reguły. Na przykład wyrazy typu mężczyzna albo poeta, które, choć same odmieniają się podług deklinacji żeńskiej, kodują rodzaj męski i wyrazy będące z nimi w związku zgody zawsze odmieniają się w rodzaju męskim. Nie jest to jedyny przykład tego typu rozdźwięku. 
tym neuro- i psycholingwistów oraz przedstawicielki i przedstawicieli lingwistyki feministycznej (więcej w sekcji 3). Warto zaznaczyć, iż są to ujęcia zróżnicowane pod względem tak metod i celów, jak i założeń badawczych. Neurolingwiści, posługując się nieinwazyjnymi technikami obrazowania czuwającego mózgu (m.in. funkcjonalnym rezonansem magnetycznym - fMRI oraz pozytonową emisyjną tomografią komputerową - PET), poszukują przede wszystkim neuronalnych korelatów kategorii rodzaju (zob. sekcja 3.1 niniejszej pracy). Psycholingwiści zajmują się raczej związkami między rodzajem naturalnym i gramatycznym oraz wpływem tego drugiego na procesy poznawcze jednostki, w tym na przykład percepcję, myślenie i pamięć (zob. sekcja 3.2). Z kolei w świetle zainteresowań lingwistyki feministycznej znajduje się charakter i zakres uwikłania kategorii rodzaju w struktury ideologiczne, mogące stanowić w konsekwencji wyraz seksizmu językowego (zob. sekcja 3.3).

\section{Systematyka kategorii rodzaju gramatycznego w języku polskim}

Rodzaj gramatyczny jest jednym z najtrudniej klasyfikowalnych elementów polskiej gramatyki. Jest to o tyle zaskakujące, iż stosunkowo rzadko spotyka się błędy związane z nieprawidłowym użyciem tej kategorii; o wiele łatwiej choćby o niewłaściwy przypadek bądź samą końcówkę deklinacyjną. Z czego zatem wynikają problemy klasyfikacyjne? Dzieje się tak ze względu na dwie istotne właściwości rodzajów w języku polskim. Pierwszą z nich jest kategoria żywotności i osobowości w rodzaju męskim, co ma bezpośrednie przełożenie na mnogość wzorów deklinacyjnych, oraz - co wiąże się z powyższym - asymetrię rodzajową w liczbie pojedynczej i mnogiej. Druga właściwość jest o tyle zastanawiająca, że dotyczy wielu części mowy $\mathrm{w}$ różnym stopniu (przede wszystkim w przypadku liczebników, o czym w dalszej części artykułu). Dlatego obecnie spojrzenie na klasyfikację rodzajów oferuje swoisty wielogłos w miejsce ujednolicenia. Co więcej, nie widać żadnych tendencji unifikacyjnych - nawet ku dwubiegunowości, jak ma to miejsce w przypadku koniugacji polskiej, gdzie czasowniki są dzielone na klasy i koniugacje w zależności od potrzeby - a klasyfikacja rodzajów nadal jest poszerzana o kolejne propozycje. Przekrój ważniejszych ujęć tej kwestii prezentuje Nowosad-Balakarczyk (2009).

Pierwsze $\mathrm{z}$ przytoczonych ujęć kategorii rodzaju zostało zaprezentowane przez Mańczaka (1956), który wyróżnił pięć klas rodzajowych $\mathrm{z}$ uwzględnieniem synkretyzmu biernika oraz łączliwość rzeczownika $\mathrm{z}$ adiektiwami, czyli następujące rodzaje liczby pojedynczej: męskoosobowy, męskozwierzęcy ${ }^{6}$, męskonieżywotny, żeński i nijaki (zob. Tab. 1).

${ }^{6}$ Obecnie większość publikacji określa ten rodzaj jako męskożywotny, lub rzadziej męsko nieosobowy. 
Tabela 1. Pięć klas rodzajowych zaproponowanych przez Mańczaka

\begin{tabular}{|c|c|c|}
\hline Biernik l. poj. & Biernik l. mn. & Rodzaj \\
\hline \multirow{2}{*}{$\begin{array}{ll}\text { dobrego } & \begin{array}{l}\text { (mężczyznę) } \\
(\mathrm{psa})\end{array} \\
\end{array}$} & dobrych (mężczyzn) & męskoosobowy (M1) \\
\hline & \multirow{4}{*}{$\begin{array}{ll}\text { dobre } & \text { (psy) } \\
& \text { (stoły) } \\
& \text { (kobiety) } \\
& \text { (dzieci) }\end{array}$} & męskozwierzęcy (M2) \\
\hline dobry $\quad$ (stół) & & męskonieżywotny (M3) \\
\hline (kobietę) & & żeński \\
\hline (dziecko) & & nijaki \\
\hline
\end{tabular}

Można zatem stwierdzić, iż w rodzaju polskim przymiotnik odmienia się przez pięć rodzajów, ale przy synkretyzmie męskoosobowy = męskozwierzęcy $\mathrm{w}$ liczbie pojedynczej, oraz męskozwierzęcy $=$ męsko nieżywotny $=$ żeński $=$ nijaki. Dalsze uogólnienie klas rodzajowych przedstawia tabela 2.

Tabela 2. Zestawienie końcówek przymiotnika

\begin{tabular}{|l|l|l|l|l|l|}
\hline Rodzaj & Męskoos. & Męskozw. & Męskonież. & Żeński & Nijaki \\
\hline Mian. l. poj. & $-\mathrm{y}$ & $-\mathrm{y}$ & $-\mathrm{y}$ & $-\mathrm{a}$ & $-\mathrm{e}$ \\
\hline Biernik l. poj. & - ego & $-\mathrm{ego}$ & $-\mathrm{y}$ & $-\mathrm{a}$ & $-\mathrm{e}$ \\
\hline Mian. l. mn. & - i & $-\mathrm{e}$ & $-\mathrm{e}$ & $-\mathrm{e}$ & $-\mathrm{e}$ \\
\hline Biernik l. mn. & $-\mathrm{ych}$ & $-\mathrm{e}$ & $-\mathrm{e}$ & $-\mathrm{e}$ & $-\mathrm{e}$ \\
\hline Dwa, oba & - aj & $-\mathrm{a}$ & $-\mathrm{a}$ & $-` e$ & $-\mathrm{e}$ \\
\hline
\end{tabular}

Inne podejście zaproponował Saloni (Saloni 1976, 1988), wyróżniając 9 klas rodzajowych na podstawie zróżnicowania form biernika liczby pojedynczej i mnogiej, ale $-\mathrm{w}$ odróżnieniu od Mańczaka $-\mathrm{z}$ uwzględnieniem liczebników. Oprócz form M1, M2, M3 i żeńskiej, dzieli on rodzaj nijaki na dwa podrodzaje:

$>$ łączące się z formą pięcioro, np. pięcioro dzieci, cieląt (N1);

> łączące się z formą pięć, np. pięć okien, krzeset (N2).

Saloni wyróżnia także trzy rodzaje pluralia tantum:

$>$ rzeczowniki typu państwo, wujostwo, łączące się $\mathrm{z}$ formami męskoosobowymi czasowników, np. państwo przyszli (P1);

$>$ rzeczowniki typu drzwi, skrzypce, łączące się z liczebnikami zbiorowymi, np. pięcioro skrzypiec (P2);

$>$ rzeczowniki typu spodnie, które mogą łączyć się $\mathrm{z}$ wyrazami pomocniczymi wyrażającymi kwantyfikację, np. pięć par spodni.

Formy $\mathrm{P}_{2}$ i $\mathrm{P}_{3}$ łączą się przy tym $\mathrm{z}$ formami niemęskoosobowymi czasownika.

Według Saloniego, choć wiele form ulega synkretyzmowi czy neutralizacji, można łatwo zbudować odpowiednie konteksty diagnostyczne pozwalające na przedstawienie wszystkich dziewięciu klas rodzajowych. Wspomniane klasy rodzajowe są skontrastowane w jednym z takich kontekstów w tabeli 3. 
Mirostaw Koziarski, Adrian P. Krysiak: Rodzaj gramatyczny...

Tabela 3. Dziewięć klas rodzajowych zaproponowanych przez Saloniego

\begin{tabular}{|l|l|l|l|l|l|l|l|l|l|}
\hline & & I & & II & & III & IV & V & \\
\hline M1 & widzę & jednego & albo & dwóch & spośród & tych & chłopców & których & lubię \\
\hline M2 & widzę & jednego & albo & dwa & spośród & tych & psów & które & lubię \\
\hline M3 & widzę & jeden & albo & dwa & spośród & tych & stołów & które & lubię \\
\hline N1 & widzę & jedno & albo & dwoje & spośród & tych & niemowląt & które & lubię \\
\hline N2 & widzę & jedno & albo & dwa & spośród & tych & okien & które & lubię \\
\hline F & widzę & jedną & albo & dwie & spośród tych & kobiet & które & lubię \\
\hline P1 & widzę & jednych & albo & dwoje & spośród tych & państwa & których & lubię \\
\hline P2 & widzę & jedne & albo & dwoje & spośród tych & skrzypiec & które & lubię \\
\hline P3 & widzę & jedne & albo & dwie pary & spośród tych & spodni & które & lubię \\
\hline
\end{tabular}

Jeszcze inne podejście zaproponował Laskowski (1999), który, zachowując zbieżność z Mańczakiem (1956), stwierdził, że podział rzeczowników na klasy rodzajowe jest wyznaczony przez łączliwość form biernikowych obu liczb. Dla tego celu buduje konteksty językowe, które dzieli na dwie grupy (Laskowski 1999: 210-211):

A1 Widzę tego nowego ...

A2 Widzę ten nowy ...

A3 Widzę to nowe ...

A4 Widzę tę (tą) nową ...

B1 Widzę tych nowych ...

B2 Widzę te nowe ...

Dowolny leksem rzeczownikowy akceptuje tylko jeden z kontekstów A1-A4 oraz jeden z kontekstów B1-B2. Dla każdej klasy rodzajowej wyodrębniona jest zatem pewna szczególna kombinacja kontekstów:

> rzeczowniki męskoosobowe - konteksty A1 i B1,

> rzeczowniki męskożywotne (nieosobowe) - konteksty A1 i B2,

$>$ rzeczowniki męsko nieżywotne - konteksty A2 i B2,

$>$ rzeczowniki nijakie - konteksty A3 i B2,

$>$ rzeczowniki żeńskie - konteksty A4 i B2.

Powyższy przekrój systemów klasyfikacji polskich rodzajów gramatycznych nie jest bynajmniej wyczerpujący; łatwo znaleźć inne podziały, skupiające się już nie tylko na formach fleksyjnych. Przedstawienie ich tutaj wszystkich byłoby jednak bezcelowe. Istotnym wnioskiem wynikającym z rozważań nad klasyfikacją rodzaju gramatycznego w języku polskim jest jednak to, iż jest to zdecydowanie kategoria bardziej zgramatykalizowana aniżeli wyrażająca płciowość. Co więcej, problem liczby pojedynczej i mnogiej oraz ich asymetrii rodzajowej - nawet w ich najprostszym ujęciu: 3 rodzaje pojedyncze (męski, żeński i nijaki) oraz 2 mnogie (męskoosobowy i żeńsko-rzeczowy) - jest w stanie skutecznie przeszkodzić $\mathrm{w}$ przeprowadzeniu interdyscyplinarnych badań nad tą kategorią.

\section{Przegląd badań nad rodzajem gramatycznym}

Jako że współczesne językoznawstwo jest dyscypliną niejednorodną odnośnie do metody, przedstawimy trzy przykładowe rodzaje podejść do zagadnienia rodzaju gramatycznego $\mathrm{w}$ trzech osobnych podsekcjach. $\mathrm{W}$ 
sekcji 3.1 zaprezentujemy wyniki badań psycholingwistycznych, w $3.2-$ neurolingwistycznych, natomiast w 3.3 wspomnimy o lingwistyce feministycznej.

\subsection{Psycholingwistyka}

Holmes i de la Bâtie (1999) porównali zdolności przypisywania rodzaju gramatycznego rzeczownikom przez natywnych użytkowników języka francuskiego i uczących się tego języka. Stwierdzili, że końcówka rzeczownika pełniła ważną, lecz tylko pomocniczą rolę w przypadku rodzimych użytkowników języka francuskiego, którzy bazowali na asocjacjach leksykalnych (lexical associations). Z kolei uczący się języka kierowali się przede wszystkim właśnie końcówką rzeczownika, charakterystyczną dla danego rodzaju. Nie sposób jednak generalizować tych wyników. Różnice między funkcjonalną organizacją L1 i L2 nadal są kwestią kontrowersyjną. Paolieri et al. (2010) piszą:

We propose that in the bilingual system, parallel to the semantic route, a direct lexical, nonsemantic route connects the languages and that the native language interacts at the level of grammatical gender with the lexical representations of the response language.

Do podobnych wniosków doszli Lemhöfer et al. (2008) oraz Lemhöfer et al. (2010). Z kolei Costa et al. (2003) podają, iż systemy klas rodzajowych w L1 i L2 są funkcjonalnie autonomiczne, a dostęp do informacji o rodzaju jest procesem automatycznym, przynajmniej w odniesieniu do produkcji mowy7:

[T]he results of this study reveal that bilingual naming performance is independent of the gender value of the words in the non-response language (...) $[\mathrm{T}]$ he relative invulnerability of the response language to the properties of the non-response language does not seem to apply at other levels of representation in which the interaction between the two languages of a bilingual seems to be present, as, for example, the phonological level and, maybe, the syntactic (Costa et al. 2003: 194).

Podobnie wyniki badań nad związkami między rodzajem gramatycznym i kategoryzacją (scil. nadawaniem przedmiotom nieożywionym - inanimate objects - cech ze względu na ich rodzaj gramatyczny) są nierozstrzygające, a często sprzeczne (np. Konishi 1993; Pérez-Pereira 1999; Sera et al. 2002; Vigliocco et al. 2004; Vigliocco et al. 2005; Tight 2006; Imai et al. 2010). Sera et al. (2002) w serii eksperymentów stwierdzili taki wpływ (tj. rodzaju

7 Lemhöfer et al. (2008) zaobserwowali odnośny efekt zgodności rodzaju również w przypadku produkcji mowy. 
gramatycznego na kategoryzację) dla języka francuskiego i hiszpańskiego, ale nie dla niemieckiego. Autorzy konkludują, iż tym samym nadawanie cech męskich i żeńskich obiektom nieożywionym zależy w dużej mierze od liczby klas rodzajów gramatycznych występujących w danym języku oraz od tego, czy rodzaj gramatyczny odpowiada naturalnemu.

Wyniki niektórych badań, opisanych przez Boroditsky et al. (2003: 65-66, 68-73, 76-77; zob. też El-Yousseph 2006; Imai et al. 2010), sugerują bezpośredni wpływ kategorii rodzaju gramatycznego na procesy poznawcze takie jak percepcja, myślenie czy pamięć. Z tymi konkluzjami polemizują Vigliocco et al. (2004), którzy co prawda donoszą o efekcie wpływu rodzaju gramatycznego na procesy poznawcze, wskazują jednak na swoiste semantyczne ograniczenia tego efektu8:

[L]anguage-specific grammatical gender effects should be stronger for semantic fields in which there is a conceptual motivation for establishing a link between gender of words and sex of the referent (such as animals), than for fields for which there is not such a clear conceptual motivation (such as tools).

Zaobserwowano również (Degani 2007), że natywni użytkownicy języka angielskiego uważają pary wyrazów o tym samym rodzaju naturalnym za bardziej znaczeniowo zbliżone (similar in meaning) niż pary wyrazów o różnych rodzajach9. Jednakże zgodność ta okazała się niedostatecznie silna, by wystąpił efekt prymowania $\mathrm{w}$ zadaniach typu LDT (lexical decision task), co sugeruje kolejne ograniczenie, tym razem w odniesieniu do rodzaju naturalnego.

Podobnie wyniki badań Pérez-Pereiry (1999) dla języka hiszpańskiego wskazują brak związku lub w najlepszym przypadku słaby związek między rodzajem gramatycznym i kategoryzacją, jako że zdaniem autorki użytkownicy danego języka (w tym wypadku dzieci hiszpańskojęzyczne) sugerują się w swych codziennych wyborach językowych raczej informacją syntaktyczną i morfofonologiczną niż semantyczną. Tłumaczy to również, dlaczego rzeczowniki o tym samym rodzaju gramatycznym są przetwarzane szybciej niż te, które mają różne rodzaje, niezależnie od tego, czy występuje związek znaczeniowy ${ }^{10}$ (Cubelli et al. 2011). Jednakże należy pamiętać, że grupa dzieci nie musi być dobrym probierzem funkcjonowania ogólnojęzykowego zdrowej jednostki dorosłej. Anderson i Lockowitz (2009) porównali zdolność do przypisywania rodzaju naturalnego rzeczownikom przez dzieci w wieku przedszkolnym z SLI

8 Zarówno Sera et al. (2002), jak i Boroditsky et al. (2003), stwierdzili efekt również dla obiektów nieożywionych.

9 Sam Degani $(2007: 19,53)$ podaje następujące przykłady: queen - cow dla pierwszego rodzaju par oraz king - waitress dla drugiego. Autorzy niniejszej pracy dystansują się do antyrojalistycznej postawy Deganiego.

${ }^{10}$ Efekt zaobserwowano dla języka hiszpańskiego i włoskiego, lecz nie angielskiego. 
(Specific Language Impairment), ich zdrowych rówieśników oraz grupę dorosłych ${ }^{11}$. Okazało się, zgodnie z założeniami autorów pracy, że dorośli osiągnęli najlepsze wyniki, z dwóch pozostałych grup większą skuteczność wykazały dzieci zdrowe. Co ciekawe, większość dzieci z SLI poprawnie korzystała ze wskazówki w postaci końcówki rzeczownika.

\subsection{Neurolingwistyka}

Prowadzone w ostatnich latach badania neurolingwistyczne nad rodzajem gramatycznym skupiały się w dużej mierze na identyfikacji neuronalnych korelatów tej kategorii. Cattaneo et al. (2009) podają, iż lewy dolny zakręt czołowy (inferior frontal gyrus - IFG) (Ryc. $1^{12}$ i 2) zaangażowany jest w kodowanie informacji o rodzaju gramatycznym. Wykorzystując przezczaszkową stymulację magnetyczną (Transcranial Magnetic Stimulation - TMS), wykazali oni, iż aktywność subpopulacji neuronów w polu Broki (BA 44, 45) (Ryc. 3 i 4) zależy od typu przetwarzanego semu wymiaru rodzaju.

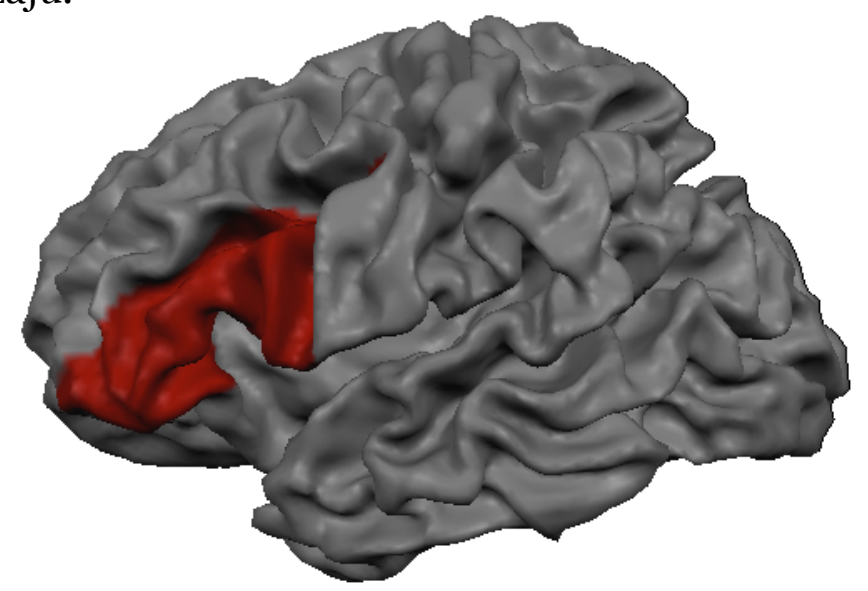

Ryc. 1 Lewy dolny zakręt czołowy.

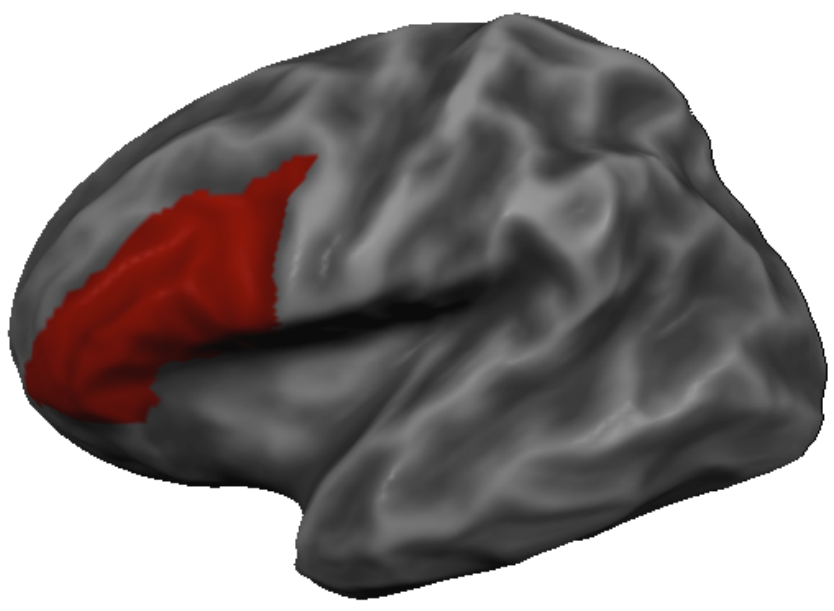

${ }^{11}$ Badanie dla języka hiszpańskiego jako L1.

12 Wszystkie skany zostały wykonane przy pomocy programu BrainVoyager Brain Tutor. 
Mirosław Koziarski, Adrian P. Krysiak: Rodzaj gramatyczny...

Ryc. 2 Lewy IFG.

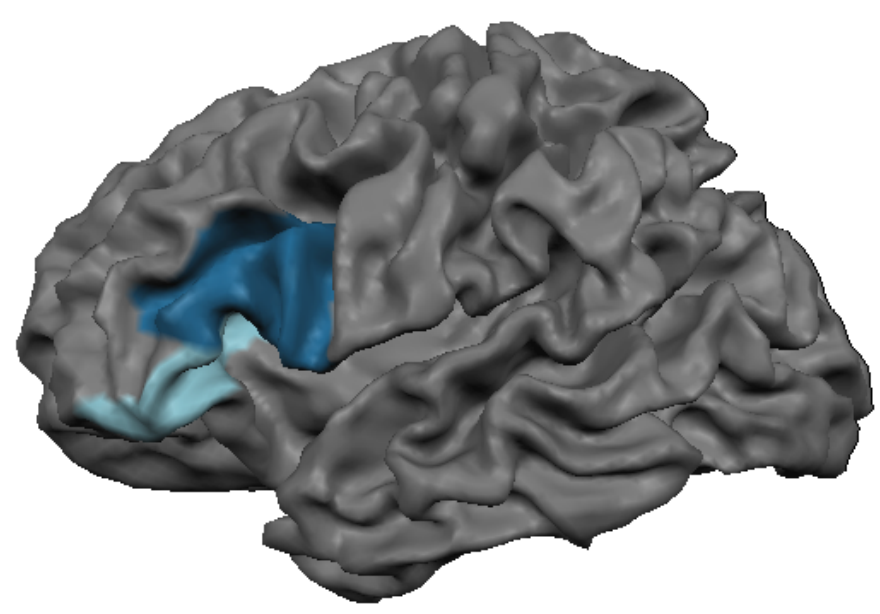

Ryc. 3 Obszar Broki.

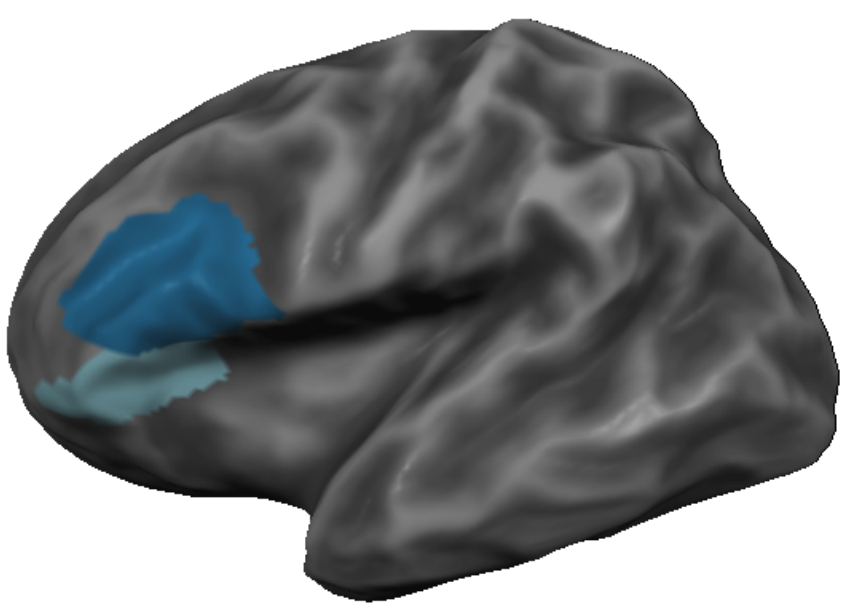

Ryc. 3 BA 44, 45 LH.

Do podobnych wniosków doszli Miceli et al. (2002), którzy zaprojektowali trzy rodzaje zadań: semantyczne, fonologiczne oraz zadanie związane $\mathrm{z}$ cechą gramatyczną (informacją zgramatykalizowaną). Wykonywanie ostatniego wiązało się $\mathrm{z}$ aktywnością ${ }^{13}$ lewego środkowego (middle) i dolnego zakrętu czołowego oraz lewego środkowego i dolnego zakrętu skroniowego (inferior temporal gyrus). Autorzy rozszerzają więc sieć przetwarzającą informację o rodzaju gramatycznym na połączenia czołowo-skroniowe (Ryc. 5 i 6 ).

\footnotetext{
${ }^{13}$ Do pomiaru wykorzystano czynnościowe obrazowanie metodą jądrowego rezonansu magnetycznego.
} 


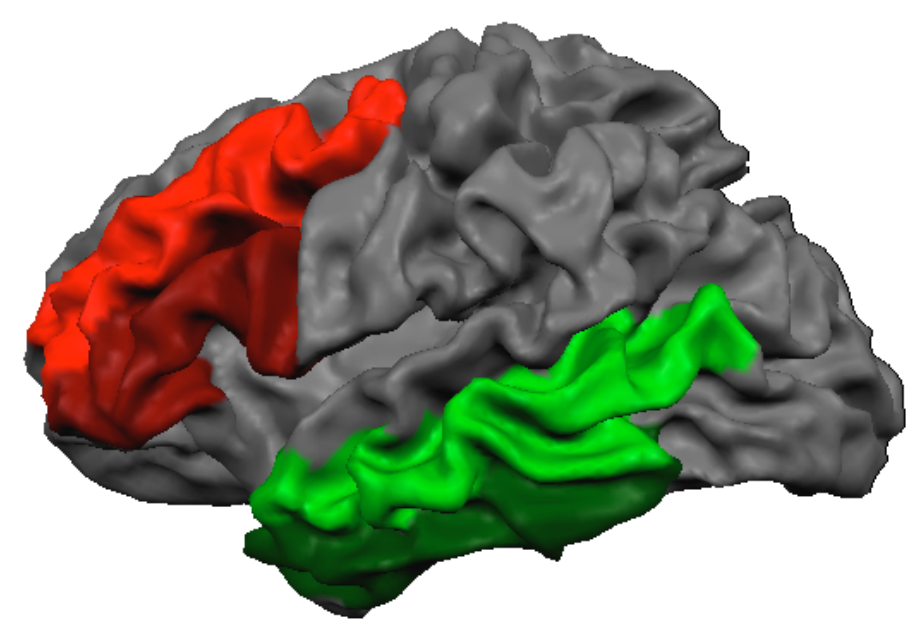

Ryc. 5 Dolny i środkowy zakręt czołowy, dolny i środkowy zakręt skroniowy $(L H)$.

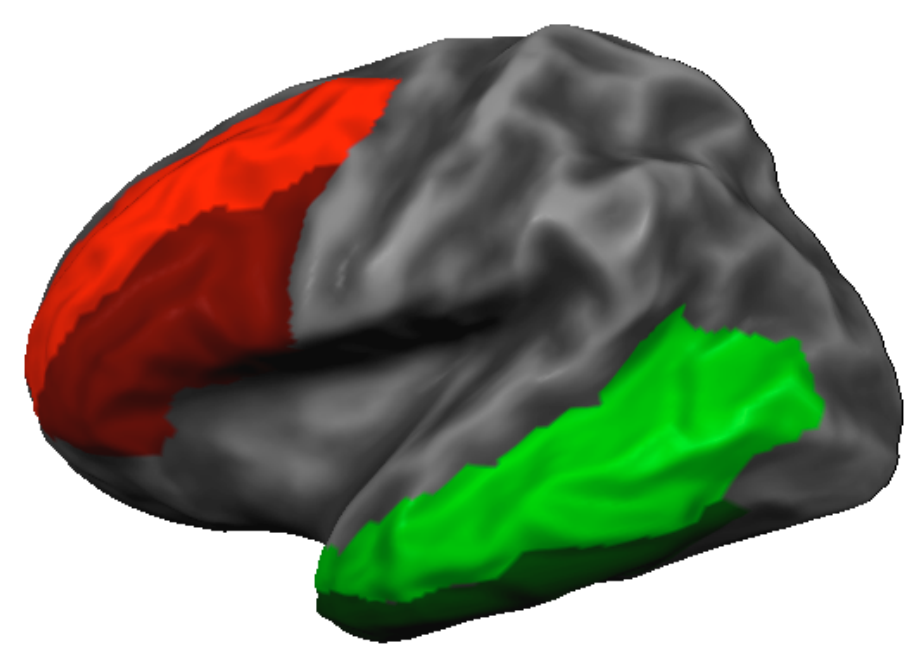

Ryc. 6 Dolny i środkowy zakręt czolowy, dolny i środkowy zakręt skroniowy $(L H)$.

Również Heim et al. (2002) stwierdzili zwiększoną aktywność w górnej części obszaru Broki podczas wymowy określnika (determiner), co wiązało się $\mathrm{z}$ wyborem rodzaju gramatycznego. Z kolei Hoffman et al. (2007) zaprojektowali dwa eksperymenty, jeden związany z percepcją, a drugi z produkcją mowy, którym poddani byli pacjenci z zaburzeniami afatycznymi z uszkodzeniami tkanki nerwowej w lewej korze czołowej oraz chorzy z lezjami w tylnej części górnego zakrętu skroniowego (posterior superior temporal gyrus - pSTG). Zadaniem uczestników eksperymentów było przypisanie rodzaju gramatycznego rzeczownikowi. Po przeanalizowaniu wyników autorzy stwierdzili, iż okolice lewej kory czołowej zaangażowane są w przetwarzanie fonologiczne, a pSTG odgrywa rolę w integracji informacji fonologicznej i leksykalnej. 
Z drugiej strony wyniki otrzymane przez Vigliocco et al. (2006) są sprzeczne z zaprezentowanymi we wspomnianych pracach. Nie stwierdzili oni aktywacji IFG podczas przetwarzania kategorii gramatycznej, lecz zaobserwowali aktywność przednich obszarów lewego IFG w odpowiedzi na słowa niosące informację związaną ze zmysłami (sensory words). Wyprowadzają stąd wniosek, iż neuronalne korelaty przetwarzania słów zależą $\mathrm{w}$ większej mierze od własności semantycznych słowa niż od gramatycznych. Odpowiedzią na podobne zastrzeżenia może być model dwóch ścieżek dostępu do rodzaju gramatycznego (a dual-route model for access to grammatical gender) (Heim et al. 2005). Zarówno w przypadku bezpośredniego (explicit, direct), jak i pośredniego (implicit) dostępu do informacji o rodzaju gramatycznym, aktywacji uległy obszary zaliczane do pola Broki (BA 44, 45) oraz sąsiadujące (m.in. BA 47), jednak charakter dostępu miał wpływ na miejsce aktywności neuronalnej. Do podobnych wniosków skłaniają wyniki otrzymane przez Hernandeza et al. (2004). Uczestnicy eksperymentu dokonywali wyboru rodzaju gramatycznego dla rzeczowników regularnych i nieregularnych. „Regularne”, czyli takie, których końcówki jednoznacznie określają rodzaj gramatyczny, a nieregularne w przeciwnym wypadku. $\mathrm{W}$ języku hiszpańskim, dla którego przeprowadzono odnośne badanie, końcówka -o (np. perro, gato) jest charakterystyczna da rodzaju męskiego, -a (np. mesa, cama) dla żeńskiego, natomiast rzeczowniki o końcówkach -e, -l, -n, -r, -s, -t, -z pozostają nieregularne. Okazało się, że podanie rodzaju gramatycznego dla rzeczowników nieregularnych angażowało zarówno bardziej złożone procesy, jak i zwiększoną aktywność w lewym IFG (BA 44/45, BA 44/6) oraz bilateralnie w okolicach wyspy (insula) (BA 47) i przedniej części zakrętu obręczy (anterior cingulate gyrus).

Równie interesujące, choć nierozstrzygające, są wyniki badań afazjologicznych. Mowę agramatyczną cechują pomijanie i/lub substytucja morfemów gramatycznych (Bastiaanse et al. 2003). Badania porównujące częstość występowania substytucji rodzajnika w języku niemieckim i włoskim ujawniły, iż dochodzi do nich częściej w przypadku niemieckiego (Bates, Wulfeck 1989). Sami autorzy tłumaczą to większą liczbą rodzajników w języku niemieckim. Niektórzy twierdzą jednak, że jest to związane $\mathrm{z}$ faktem, iż w języku włoskim rodzajnik niesie informację tylko o rodzaju, $\mathrm{w}$ niemieckim natomiast o rodzaju oraz przypadku, co $\mathrm{w}$ konsekwencji oznaczałoby, że substytucje te wynikają z zaburzeń na poziomie składniowym (Bastiaanse et al. 2003). Badanie przeprowadzone przez tych autorów wykazało, że u natywnych użytkowników języka holenderskiego i niemieckiego z agramatyzmem ponad $85 \%$ substytucji rodzajnika wynikało z problemów z przetwarzaniem syntaktycznym ${ }^{14}$.

14 Warto jednak zwrócić uwagę na fakt, iż stwierdzono również pewną różnicę miedzyjęzykową, mianowicie w przypadku natywnych użytkowników języka holenderskiego $\mathrm{z}$ agramatyzmem częściej dochodzi do pomijania rodzajnika niż jego substytucji, natomiast u rodzimych użytkowników języka niemieckiego $\mathrm{z}$ tym samym zaburzeniem jest na odwrót, co porównać można z wynikami osiągniętymi przez Batesa i Wulfecka (1989). 
Omówione badania zostały przeprowadzone przede wszystkim dla języka włoskiego, niemieckiego, angielskiego i hiszpańskiego. Nie są nam znane badania tego typu wykonane na rodzimych użytkownikach języka polskiego.

\subsection{Lingwistyka feministyczna}

Ponadto współczesne badania nad rodzajem gramatycznym prowadzone są w ramach popularnego dziś podejścia feministycznego (lingwistyka feministyczna). Skupiając się w dużej mierze na uwikłaniu kategorii rodzaju gramatycznego $\mathrm{w}$ dyskurs społeczno-ideologiczny, prace te obejmują zarówno kwestie ogólne (Brzozowska 2002), jak i bardziej szczegółowe, na przykład zagadnienie rodzaju gramatycznego nazwy zawodu jako nośnika statusu społecznego (Kamasa 2006, 2007; Dąbrowska 2008). Kamasa (2007: 77) stwierdza: „dla osób objętych prezentowanymi tutaj badaniami żeński rodzaj gramatyczny nazwy zawodu jest dość silnym nośnikiem skojarzeń związanych z cechami przypisywanymi stereotypowym kobietom”.

Mimo iż wyniki wspomnianych analiz odnoszą się do współczesnej polszczyzny i obecnego stanu rzeczy, podobne wnioski są czasem ekstrapolowane, jak czyni to Grzegorczykowa (2001: 163):

„Jako przykład faktów gramatycznych można podać kategorię męskoosobowości w polszczyźnie, która może być traktowana jako świadectwo uprzywilejowanej pozycji mężczyzn w dawnej Polsce: zrównuje ona gramatycznie kobiety ze światem nie-osób: por. szafy, drzewa, psy, kobiety stały, ale mężczyźni stali” [wyróżnienia w oryginale].

Tak więc zagadnienia dotyczące rodzaju gramatycznego rzeczownika są przedmiotem zainteresowania zarówno językoznawstwa synchronicznego (zob. też punkt 4), jak i diachronicznego. Warto dodać, iż nakreślonym wyżej przekonaniom towarzyszy często mocna teza o bliskich związkach między językiem a ogólnym funkcjonowaniem poznawczym jednostki, scil. wpływie języka na rzeczywistość społeczną, gdzie język jest rozumiany jako „narzędzie służące do tworzenia światów społecznych” (por. Kamasa 2007: 67). W konsekwencji używanie (resp. nieużywanie) pewnych form językowych stanowi wyraz, jak to nazywa Dąbrowska (2008), „seksizmu językowego”.

Odmienną kategorię zainteresowań badaczy stanowią kwestie normatywne, które jednak wykraczają poza ramy tego artykułu oraz przerastają kompetencje autorów (zob. np. Satkiewicz et al. 1973; Jadacka 2006: 126-132). 


\section{Synchroniczne spojrzenie na kategorię rodzaju gramatycznego $w$ języku polskim}

Jednym z zasadniczych pytań stawianych przez lingwistykę feministyczną oraz psycholingwistykę jest, czy i w jakim stopniu płeć jest odzwierciedlana w kategorii rodzaju gramatycznego?

Najbardziej oczywistymi przykładami są nazwy funkcji i zawodów pełnionych zazwyczaj przez obie płci, tu: wujek i ciocia, aktor i aktorka. Pierwsze różnice dają się jednak już zauważyć w przypadku zawodów silnie kojarzonych $\mathrm{z}$ daną płcią - stąd w konsternację może wprawić próba stworzenia żeńskiej formy od grafika komputerowego, czy męskiej od przedszkolanki. Jeszcze ciekawszym dysonansem cechują się słowa król «monarcha sprawujący najwyższą władzę w królestwie, koronowany władca; także: tytuł tej osoby» i królowa «samodzielna monarchini sprawująca najwyższą władzę w królestwie - koronowana władczyni lub żona króla; także: tytuł tej osoby» (UJSP 2006) i wynikający z tej różnicy spór historyków o to, czy władcą Polski była królowa Jadwiga, czy król Jadwiga (Grodecki 1995: 215). Zastanawiający jest fakt językowy, iż choć mąż królowej niepełniący funkcji władcy królem nie jest, obserwuje się synkretyzm dwóch funkcji (władczyni i/lub żona) w przypadku słowa królowa. Trudno nie dostrzec tutaj implikacji społeczno-historycznych ów synkretyzm odzwierciedla fenomen kobiety-władcy jako rzadki, co się przekłada na brak odrębnej terminologii. Jednak o wiele silniejsze nacechowanie ujawnia się w przypadku nazw zawodów, które cieszą się dużym poważaniem społecznym, np. psycholog, którego forma żeńska psycholożka - uznawana jest przez dużą część populacji za formę ujmującą (Warchol-Schlottmann 2006). Co więcej, bardzo często ujawnia się też asymetryczność semantyczna, np. sekretarz - sekretarka, choć słowotwórczo spokrewnione, mają zgoła różne znaczenia: podczas gdy sekretarz to najczęściej «stanowisko osoby kierującej pracą administracyjną i organizacyjną w instytucjach i urzędach» (dla obojga płci), sekretarka to zawsze "pracownica zajmująca się korespondencją, przyjmująca interesantów, załatwiająca sprawy bieżące związane $\mathrm{z}$ działalnością jakiejś osoby lub instytucji» (UJSP). Asymetryczność ta przejawia się również na poziomie społecznego odbioru konkretnych nazw, w tym wypadku nazw zawodów (Kamasa 2007: 67-77). Szczególnie symptomatyczny jest przykład pary pani położna - pani położny (Kamasa 2007: 70). O ile ta pierwsza jest nade wszystko „zaangażowana w pracy i solidnie wykonuje swoje obowiązki”, to druga „może okazać się ginekologiem $\mathrm{z}$ aspiracją na pedofila” oraz „traktuje pacjentki przedmiotowo, zwracając się do nich: «nie krzycz babo, bo nie pierwsza rodzisz»". Więcej przykładów znaleźć można w odnośnej pracy.

Nowosad-Bakalarczyk (2009) przedstawia wiele interesujących z punktu widzenia niniejszej pracy fenomenów leksykalnych. Jednym z nich są słowa, które, choć niezwiązane z płcią bezpośrednio, kodują informację na temat osobników tylko jednej płci na podstawie stereotypów, np. pajac, brutal, bydlak, impotent czy szmata, trajkotka, mężatka, dama 
(Nowosad-Bakalarczyk 2009: 18-23). Kolejnym z takich zjawisk jest występowanie rzeczowników takich jak odludek, odbiorca, osoba, postać, świadek, smakosz czy satyryk, które, choć mają stały rodzaj gramatyczny (męski lub żeński), odnoszą się do obu płci jednocześnie. Jeszcze inne wyrazy - jak wspomniany psycholog, czy sierota - nie zmieniają swojej formy $\mathrm{w}$ związku $\mathrm{z}$ płcią, ale wymuszają tę zmianę na słowach podlegających związkowi zgody: ten pan psycholog(m) był $\rightarrow$ ta pani psycholog $^{(\mathrm{f})}$ była; ten $\operatorname{sierota}^{(\mathrm{m})}$ był $\rightarrow$ ta sierota $^{(\mathrm{f})}$ była.

Zainteresowanie rozbieżnościami w wartościowaniu i kojarzeniu rodzaju z płcią nie kończy się jednak na ludziach, którym kategorię płci w większości przypadków jednak łatwo przypisać (z nielicznymi wyjątkami: chociaż dziecko jest rodzaju nijakiego, a może kodować obie płci, to słowo człowiek jest już rodzaju męskiego, mimo identycznej niemal sytuacji językowej; co więcej, hemafrodyta, oznaczający bezpłciowca, obojnaka, jest rodzaju męskiego (co wiemy dzięki odmianie przymiotnikowej), a odmienia się wedle deklinacji żeńskiej IV.

Co do pojęć abstrakcyjnych, to $\mathrm{z}$ jednej strony są one zdominowane przez rodzaj nijaki, np. nazwy czynności (pranie, picie, jedzenie, ptywanie, badanie, zachmurzenie), wartości (dobro, zło), zjawisk (zimno, ciepło), czy niektórych obszarów (rozlewisko, rykowisko, pogorzelisko), jednak to rodzaj żeński opisuje większość nazw uczuć (mitość, nienawiść, przyjemność), które też są pojęciami abstrakcyjnymi, inherentnie bezpłciowymi. Choroba i przegrana, czy też brak, niedobór albo zanik to kolejne przykłady wyrazów abstrakcyjnych, które jednak nijakie (w sensie gramatycznym) nie są. W przypadku przedmiotów namacalnych entropia rodzajowa jest na tyle wysoka, iż trudno, bez odwołania się do badań statystycznych, dostrzec zależności - nie szukając daleko: ten fotel, ta tawka, to krzesto.

Tak duże zróżnicowanie rodzajów jest wysoce zastanawiające i z pewnością godne zbadania pod kątem związku między wyobrażeniami o płci a rodzajem gramatycznym rzeczowników. Trzeba jednak przy tym uważać na liczne różnice mające swe źródło w czynnikach zewnętrznych. Jednym $\mathrm{z}$ takich czynników są liczne zapożyczenia internacjonalizmów w języku polskim z języków zachodnich. Na przykład Jasiaczyk (2010) porównuje kilkaset internacjonalizmów polskich i rosyjskich, które różnią się rodzajem z powodu innego języka źródłowego (najczęściej francuskiego i włoskiego); uwzględnione są wszystkie kombinacje kontrastujące trzy główne rodzaje liczby pojedynczej, tj. pary (polski - rosyjski) męski żeński, męski - nijaki, żeński - męski, żeński - nijaki, nijaki - męski, nijaki - żeński. Dodatkowo w przypadku takich studiów kontrastywnych należy oczywiście uwzględnić same różnice międzyjęzykowe języków źródłowych, wyrażające się między innymi w formie fonologicznej wyrazów:

[N]ajbardziej pospolite wyrazy, których związek semantyczny mógłby być zaznaczony przy pomocy rodzaju, często różnią się między sobą całkowicie pod względem formy fonologicznej: brak 
Mirostaw Koziarski, Adrian P. Krysiak: Rodzaj gramatyczny...
odpowiedniości fonologicznej, jaki można zaobserwować w parach angielskich i francuskich boy : girl, garçon : fille 'chtopiec : dziewczyna', jest bardziej charakterystyczny niż paralelizm między włoskimi ragazzo : ragazza (Lyons 1976: 320).

\section{Badanie wlasne}

Autorzy postanowili przeprowadzić własne badanie ankietowe, mające stanowić próbę ewaluacji intuicji natywnych użytkowników języka polskiego w odniesieniu do rodzaju gramatycznego rzeczownika. Wyniki zostaną przedstawione w drugiej części artykułu (Krysiak, Koziarski w przygotowaniu). 


\section{Bibliografia}

Anderson, R.T., Lockowitz, A. 2009. How do children ascribe gender to nouns? A study of Spanish-speaking children with and without specific language impairment. Clinical Linguistics and Phonetics, vol. 23(7), pp. 489-506.

Bańczerowski, J., Pogonowski, J., Zgółka, T. 1982. Wstęp do językoznawstwa. Poznań: Wydawnictwo Naukowe UAM.

Bastiaanse, R., Jonkers, R., Ruigendijk, E., Van Zonneveld, R. 2003. Gender and case in agrammatic production. Cortex, vol. 39(3), pp. 405-417.

Bates, E., Wulfeck, B. 1989. Comparative aphasiology: A cross-linguistic approach to language breakdown. Aphasiology, vol. 3, pp. 111-142.

Boroditsky, L., Schmidt, L., Phillips, W. 2003. Sex, Syntax and Semantics. w: D. Gentner, S. Goldin-Meadow (Eds.) Language in Mind: Advances in the Study of Language and Thought. Cambridge, MA: MIT Press. pp. 61-79.

Brzozowska, D. 2002. The Role of Gender in Language Communication. Investigationes Linguisticae, vol. VIII, pp. 1-5.

Cattaneo, Z., Devlin, J.T., Vecchi, T., Silvanto, J. 2009. Dissociable neural representations of grammatical gender in Broca's area investigated by the combination of satiation and TMS. NeuroImage, vol. 47(2): 700-704.

Costa, A., Kovacic, D., Franck, J., Caramazza, A. 2003. On the Autonomy of the Grammatical Gender Systems of the Two Languages of a Bilingual. Bilingualism: Language and Cognition, vol. 6(3), pp. 181-200.

Cubelli, R., Paolieri, D., Lotto, L., Job, R. 2011. The effect of grammatical gender on object categorization. Journal of Experimental Psychology: Learning, Memory, and Cognition, vol. 37(2), pp. 449-46o.

Dąbrowska, M. 2008. Rodzaj gramatyczny a seksizm. Studia Linguistica Universitatis Iagellonicae Cracoviensis, vol. 125, pp. 67-78.

Degani, T. 2007. The Semantic Role of Gender: Biological and Grammatical Gender Match Effects in English and Spanish. (nieopublikowana praca magisterska, University of Pittsburgh) [@:] http://etd.library.pitt.edu/ETD/available/etd-04102007153018/unrestricted/Degani_Master_April_2007.pdf [data dostępu: luty, 2011]

Dubisz, S. (red.) 2006. Uniwersalny słownik języka polskiego. Warszawa: Wydawnictwo Naukowe PWN (wersja elektroniczna 2.0).

El-Yousseph, N. 2006. Sex and Size: The Influence of Grammatical Gender on Object Perception in English and German. (A Senior Honors Thesis, The Ohio State University) [@:]

https://kb.osu.edu/dspace/bitstream/handle/1811/6573/thesisfinal_1.pdf;jse ssionid $=38 \mathrm{BDBoDFC} 77000429 \mathrm{E} 4835274 \mathrm{~A} 4 \mathrm{D} 6 \mathrm{C} 29$ ? sequence $=1$ [data dostępu: luty, 2011]

Grodecki, R., Zachorowski, S., Dąbrowski, J. 1995. Dzieje Polski średniowiecznej. Tom 2. Od roku 1333 do 1506. Kraków: Universitas Platan.

Grzegorczykowa, R. 2001. Wprowadzenie do semantyki językoznawczej. Warszawa: Wydawnictwo Naukowe PWN.

Heim, S., Alter, K., Friederici, A.D. 2005. A dual-route account for access to grammatical gender: evidence from functional MRI. Anatomy and Embryology, vol. 210(5-6), pp. 473-483.

Heim, S., Opitz, B., Friederici, A.D. 2002. Broca's area in the human brain is involved in the selection of grammatical gender for language production: 
evidence from event-related functional magnetic resonance imaging. Neuroscience Letters, vol. 328(2), pp. 101-104.

Hernandez, A.E., Kotz, S.A., Hofmann, J., Valentin, V.V., Dapretto, M., Bookheimer, S.Y. 2004. The neural correlates of grammatical gender decisions in Spanish. NeuroReport, vol. 15(5), pp. 863-866.

Hofmann, J., Kotz, S.A., Marschhauser, A., Yves von Cramon, D., Friederici, A.D. 2007. Lesion-site affects grammatical gender assignment in German: perception and production data. Neuropsychologia, vol. 45(5), pp. 954-965.

Holmes, V.M., de la Bâtie, B.D. 1999. Assignment of Grammatical Gender by Native Speakers and Foreign Learners of French. Applied Psycholinguistics, vol. 20(4), pp. 479-506.

Imai, M., Schalk, L., Saalbach, H., Okada, H. 2010. Influence of grammatical gender on deductive reasoning about sex-specific properties of animals. w: R. Catrambone, S. Ohlsson (Eds.) Proceedings of the 32nd Annual Conference of the Cognitive Science Society. Austin, TX: Cognitive Science Society. pp. 116o1165 .

Jadacka, H. 2006. Kultura języka polskiego. Fleksja, słowotwórstwo, składnia. Warszawa: Wydawnictwo Naukowe PWN.

Jasiaczyk, М. 2010. Различия в грамматическом роде в словах иностранного происхождения в польском $u$ русском языках Магистерская (nieopublikowana praca magisterska; Uniwersytet im. Adama Mickiewicza w Poznaniu)

Kamasa, V. 2006. Przykład metodologii badań nad językiem jako nośnikiem statusu. Investigationes Linguisticae, vol. XIII, pp. 102-117.

Kamasa, V. 2007. Fryzjer czy fryzjerka? Rodzaj gramatyczny nazwy zawodu jako nośnik statusu społecznego. Investigationes Linguisticae, vol. XV, pp. 56-79.

Konishi, T. 1993. The semantics of grammatical gender: a cross-cultural study. Journal of Psycholinguistic Research, vol. 22(5), pp. 519-534.

Krysiak, A.P., Koziarski, M. Rodzaj gramatyczny rzeczownika jako nośnik informacji pozagramatycznej II. Próba ewaluacji intuicji natywnych użytkowników języka polskiego w odniesieniu do rodzaju gramatycznego rzeczownika - badanie ankietowe (w przygotowaniu)

Laskowski, R. 1999. Rodzaj gramatyczny. w: R. Grzegorczykowa, R. Lakowski, H. Wróbel (red.) Gramatyka wspótczesnego języka polskiego. Morfologia. Wydanie III poprawione. Warszawa: Wydawnictwo Naukowe PWN. pp. 207213.

Lemhöfer, K., Schriefers, H., Hanique, I. 2010. Native language effects in learning second-language grammatical gender: A training study. Acta Psychologica, vol.135(2), pp. 150-158.

Lemhöfer, K., Spalek, K., Schriefers, H. 2008. Cross-language effects of grammatical gender in bilingual word recognition and production. Journal of Memory and Language, vol. 59(3), pp. 312-330.

Lyons, J. 1976. Wstęp do językoznawstwa. Warszawa: Wydawnictwo Naukowe PWN.

Mańczak, W. 1956. Ile jest rodzajów w języku polskim? Język Polski, vol. XXXVI, Z. 2, pp. 116-121.

Miceli, G., Turriziani, P., Caltagirone, C., Capasso, R., Tomaiuolo, F., Caramazza, A. 2002. The Neural Correlates of Grammatical Gender: An fMRI Investigation. Journal of Cognitive Neuroscience, vol. 14(4), pp. 618-628.

Nowosad-Balakarczyk, M. 2009. Płeć a rodzaj gramatyczny we wspótczesnej polszczyźnie. Lublin: Wydawnictwo UMCS. 
Paolieri, D., Cubelli, R., Macizo, P., Bajo, T., Lotto, L., Job, R. 2010. Grammatical gender processing in Italian and Spanish bilinguals. Quarterly Journal of Experimental Psychology, vol. 63(8), pp. 1631-1645.

Pérez-Pereira, M. 1999. The acquisition of gender: what Spanish children tell us. Journal of Child Language, vol. 18(3), pp. 571-590.

Pogonowski, J. 2006. Ile jest języków? Investigationes Linguisticae, vol. XIV, pp. 1-12.

Saloni, Z. 1976. Kategoria rodzaju we współczesnym języku polskim. w: Kategorie gramatyczne grup imiennych. Materiaty konferencji $w$ Zawoi, 13-15 XII 1974. Wrocław: Zakład Narodowy im. Ossolińskich. pp. 43-78.

Saloni, Z. 1988. O tzw. formach nieosobowych męskoosobowych w polszczyźnie. Biuletyn Polskiego Towarzystwa Językoznawczego, vol. XLI, pp. 155-166.

Satkiewicz, H., Buttler, D., Kurkowska H. 1973. Kultura języka polskiego. Warszawa: PWN.

Sera, M.D., Elieff, C., Forbes, J., Burch, M.C., Rodriguez, W., Dubois, D.P. 2002. When language affects cognition and when it does not: An analysis of grammatical gender and classification. Journal of Experimental Psychology: General, vol. 131, pp. 377-397.

Tight, D.G. 2006. The Relationship between Perceived Gender in L1 English and Grammatical Gender in L2 Spanish. w: Selected Proceedings of the 7th Conference on the Acquisition of Spanish and Portuguese as First and Second Languages. Somerville, MA. pp. 149-160.

Vigliocco, G., Vinson, D.P., Paganelli, F. 2004. Grammatical gender and meaning. Proceedings of the 26th Meeting of the Cognitive Science Society. [@:] http://www.psychol.ucl.ac.uk/language/papers/vvp_cogsci.pdf [data dostępu: luty, 2011]

Vigliocco, G., Vinson, D.P., Paganelli, F., Dworzynski, K. 2005. Grammatical gender effects on cognition: implications for language learning and language use. Journal of Experimental Psychology: General, vol. 134(4), pp. 501-520.

Vigliocco, G., Warren, J., Siri, S., Arciuli, J., Scott, S., Wise, R. 2006. The role of semantics and grammatical class in the neural representation of words. Cerebral Cortex, vol. 16(12), pp. 1790-1796.

Warchol-Schlottmann, M. 2006. Dlaczego pani psycholog Nowak nie chce być psycholożką Nowak. Alma Mater, vol. 82, pp. 42-45. 